\title{
Effects of Sowing Time on the Seed Yield of Quinoa (Chenopodium quinoa Willd) in South Kanto, Japan
}

\author{
Katsunori Isobe*, Hikaru Sugiyama, Daisuke Okuda, Yudai Murase, Hiroki Harada, \\ Misa Miyamoto, Syunsuke Koide, Masao Higo, Yoichi Torigoe \\ College of Bioresource Sciences, Nihon University, Kanagawa, Japan \\ Email: ${ }^{*}$ isobe64@brs.nihon-u.ac.jp
}

Received 13 February 2016; accepted 20 March 2016; published 23 March 2016

Copyright (C) 2016 by author and Scientific Research Publishing Inc. This work is licensed under the Creative Commons Attribution International License (CC BY). http://creativecommons.org/licenses/by/4.0/

(c) (i) Open Access

\begin{abstract}
The objective of the present study was to determine the optimum sowing time of three quinoa ecotypes (Altipllano, sea level, and valley) for high seed yields in south Kanto, Japan. Pot experiments were conducted in the experimental field at Nihon University during 2011, 2012, 2013, and 2014. In this experiment, the following quinoa varieties were used NL-6, Baer Cajon and Cauquenes (sea-level type), Amarilla de Marangani, Blanca de Junin, CICA-127, ECU-420, ECU-525, Ingapirica, and Narino (valley type), 94R and Isluga (Altiplano type). The quinoa seeds were sown on March 29, June 17 and September 22, 2011; March 27, June 17 and August 28, 2012; March 26, June 15 and 5 September 5, 2013; and March 27, June 17 and August 28, 2014. When the sea-level type and Altiplano type seeds were sowed from March to September, the seeds could be gained in all sowing plots. However, the seed weights of all varieties were the highest in the sowing plots of March. And the seed weights in the sowing plot of March were significantly higher than that in the other sowing plots. The sea-level type and Altiplano type quinoa had almost the same seed growth reaction for day length and day temperature. Thus, to gain a high seed yield of the sea-level and Altiplano type quinoa, March was the optimum sowing time in south Kanto, Japan. When the valley-type seeds were sowed from March to June, the seeds could not be gained, except in 2012. In 2012, the seed weights and seed numbers in sowing plots of March and June were significantly lower than those in the sowing plot of September. Thus, to obtain a high seed yield of the valley type quinoa, the optimum sowing time in south Kanto, Japan was from August to September.
\end{abstract}

\section{Keywords}

Day Length, Day Temperature, Ecotype, Sowing Time, Quinoa

\footnotetext{
${ }^{*}$ Corresponding author.
}

How to cite this paper: Isobe, K., Sugiyama, H., Okuda, D., Murase, Y., Harada, H., Miyamoto, M., Koide, S., Higo, M. and Torigoe, Y. (2016) Effects of Sowing Time on the Seed Yield of Quinoa (Chenopodium quinoa Willd) in South Kanto, Japan. Agricultural Sciences, 7, 146-153. http://dx.doi.org/10.4236/as.2016.73014 


\section{Introduction}

Quinoa (Chenopodium quinoa WILLD) is a crop species that has been domesticated in South America since 1000 years [1] [2]. At present, this species is distributed from Colombia to Southern Chile and from sea level up to $>4000 \mathrm{~m}$ above sea level. This species is classified into certain ecotypes (including the Altiplano, sea-level, and valley types) based on the place of origin [3]-[5]. Altiplano type quinoa originates around Lake Titicaca in Peru or Bolivia, sea-level type quinoa originates in Southern Chile, and valley-type quinoa originates in the high altitude (2000 and $3000 \mathrm{~m}$ above sea level) of Bolivia [6]-[8]. It has been shown that there are differences in the effects of day length and day temperature after flowering on seed formation and seed growth among ecotypes [9]-[14]. For example, Ujiie et al. [14] reported that the growth of NL-6 seeds (sea-level type) was not suppressed under $11 \mathrm{~h}$ and $14 \mathrm{~h}$ day length, and that Amarillade Marangani (valley type) was severely suppressed under $14 \mathrm{~h}$ day length, and was not suppressed under $11 \mathrm{~h}$ day length. The day length in south Kanto varies from approximately $10 \mathrm{~h}$ to $14.5 \mathrm{~h}$ [14]. Thus, the difference in sowing time in south Kanto may affect the seed growth and yield in valley-type quinoa. In many countries, quinoa has been tested under different climate conditions with varied yield according to sowing time [11] [14] [15]. It is considered that the sowing time has a great effect on quinoa yield.

The decrease in day temperature after flowering from $30^{\circ} \mathrm{C}$ to $20^{\circ} \mathrm{C}$ promoted seed growth of the sea-level type quinoa. In contrast, the seed weight of the valley type quinoa was the heaviest at a day temperature of $20^{\circ} \mathrm{C}$ after flowering [12]. Photoperiods applied after flowering affected seed growth, and the response to photoperiod was strongly affected by temperature [9] [11] [16]. Thus, the optimum sowing time for a high seed yield might differ among ecotypes in Japan. At present, all food imports of quinoa seeds were from South America, Bolivia and Peru. However, because the nutritional characteristics of quinoa seeds were reassessed [17]-[20], resulting in an increase in the amount of quinoa consumption in the future. There was good potential for increased production of quinoa in the United States and in certain parts of Africa and Asia [11]. We believed that the cultivation of quinoa would become more important in Japan. The objective of the present study was to determine the optimum sowing time of three quinoa ecotypes (Altiplano, sea level, and valley) for high seed yields in south Kanto, Japan.

\section{Material and Method}

\subsection{Plots and Cultivation System}

Pot experiments were conducted in the experimental field at Nihon University (Fujisawa-city, Kanagawa, Japan; lat. $35^{\circ} 38^{\prime} 41^{\prime \prime N}$, long. $139^{\circ} 47^{\prime} 15^{\prime} \mathrm{E}$ ) during 2011, 2012, 2013, and 2014 to clarify the optimum sowing time of quinoa in south Kanto, Japan. In this experiment, the following quinoa varieties were used NL-6, Baer Cajon and Cauquenes (sea-level type) during 2011, the Amarilla de Marangani, Blanca de Junin, CICA-127, and ECU-420 (valley type) during 2012, the 94R and Isluga (Altiplano type) and Blanca de Junin, ECU-525 and Ingapirica (valley type) during 2013, and the 94R and Isluga (Altiplano type), Cauquenes (sea-level type), and Narino (valley type) during 2014. In 1/2000 a pots containing $8 \mathrm{~kg}$ of field soil (Andosol) and $17.14 \mathrm{~g}$ of compound fertilizer (14:14:14), 20 seeds per pot were sown on March 29, June 17 and September 22, 2011; March 27, June 17 and August 28, 2012; March 26, June 15 and 5 September 5, 2013; and March 27, June 17 and August 28 , 2014. The seedlings were thinned to three plants per pot at the second or third leaf stage. All pots were placed randomly outside the experimental field from sowing to maturity, and weeds, diseases, and insects were controlled as necessary during the cultivation period.

\subsection{Measurement of Growth, Seed Weight at Maturity and Environment Data}

Dates of flowering (the date of flowering of 60\% plants) and maturity (the date of leaf color change from green to yellow of all plants) were recorded. At maturity, seed weight per pot, 1000 seeds weight and seeds number per pot were analyzed by 10 pots. Quinoa seeds with a diameter $>1.0 \mathrm{~mm}$ were used for the seed weight survey. The data of temperature from flowering to maturity were obtained from the weather station of Automated Meteorological Data Acquisition System (Japan Meteorological Agency), Tsujido, which was the nearest to the experimental field. The data of day length from flowering to maturity were recorded from the Chronological Scientific Tables Website (http://www.rikanenpyo.jp). 


\subsection{Statistical Analysis}

All values were expressed as means. The data were statistically analyzed, and significant differences among the sowing plots of each variety were determined by the Tukey multiple comparisons test using the Kaleida Graph ver. 4.0 software.

\section{Results}

\subsection{Day Length and Maximum Temperature from Flowering to Maturity}

Table 1 shows the date, day length and maximum temperature of each day from flowering to maturity of the Altiplano type quinoa. In the sowing plots of March, the flowering period ranged from late in May to June, and plants matured in July. In the sowing plots of June, the flowering period ranged from late July to August, and plants matured in September. In the sowing plots of September, the flowering period ranged from late October to early November, and plants matured from December to January. The day lengths from flowering to maturity were $>14 \mathrm{~h}, 12-14 \mathrm{~h}$, and $9-11 \mathrm{~h}$ in the sowing plots of March, June, and September, respectively. The maximum temperatures of each day from flowering to maturity ranged between $21.7^{\circ} \mathrm{C}$ and $32.1^{\circ} \mathrm{C}, 26.8^{\circ} \mathrm{C}$ and $35.2^{\circ} \mathrm{C}$, and $7.6^{\circ} \mathrm{C}$ and $22.3^{\circ} \mathrm{C}$ in the sowing plots of March, June, and September, respectively.

Table 2 shows the date, day length and maximum temperature of each day from flowering to maturity of the sea-level type quinoa. In the sowing plots of March, the flowering period ranged from mid-to late May, and plants matured in July. In the sowing plots of June, the flowering period ranged from mid-July to August, and plants matured from late August to mid-September. In the sowing plots of September, the flowering period occurred in November, and plants matured in December. The day lengths from flowering to maturity were from 12.4 to $14.3 \mathrm{~h}, 12.4$ to $14.3 \mathrm{~h}$, and 9.5 to $10.5 \mathrm{~h}$ in the sowing plots of March, June, and September, the maximum

Table 1. Growth stage and day length from flowering to maturity stage of Altiplano type quinoa.

\begin{tabular}{|c|c|c|c|c|c|c|c|}
\hline Year & Variety & Plot & Sowing date & Flowering stage & Maturity stage & $\begin{array}{l}\text { Day length from } \\
\text { flowering to } \\
\text { maturity (h) }\end{array}$ & $\begin{array}{l}\text { Maximum } \\
\text { temperature of each } \\
\text { day from flowering to } \\
\text { maturity }\left({ }^{\circ} \mathrm{C}\right)\end{array}$ \\
\hline \multirow{6}{*}{2013} & \multirow{3}{*}{$94 \mathrm{R}$} & March & March 26 & May 29 & July 3 & $14.2-14.4$ & $21.7-28.6$ \\
\hline & & June & June 15 & August 2 & September 5 & $12.4-14.0$ & $26.9-35.2$ \\
\hline & & September & September 5 & November 3 & January 6 & $9.5-11.1$ & $7.6-20.7$ \\
\hline & \multirow{3}{*}{ Isluga } & March & March 26 & June 10 & July 20 & $14.1-14.4$ & $22.0-32.1$ \\
\hline & & June & June 15 & July 30 & September 5 & $12.4-14.0$ & $28.0-35.0$ \\
\hline & & September & September 5 & October 22 & December 11 & $9.5-11.1$ & $10.7-22.3$ \\
\hline \multirow{4}{*}{2014} & \multirow{2}{*}{$94 \mathrm{R}$} & March & March 27 & May 26 & July 5 & $14.1-14.3$ & $21.7-28.6$ \\
\hline & & June & June 30 & August 13 & September 14 & $12.2-13.4$ & $26.8-32.0$ \\
\hline & \multirow{2}{*}{ Isluga } & March & March 27 & May 30 & July 1 & $14.2-14.3$ & $21.7-28.6$ \\
\hline & & June & June 17 & August 26 & September 16 & $12.2-13.0$ & $26.8-31.8$ \\
\hline
\end{tabular}

Table 2. Growth stage and day length from flowering to maturity stage of sea-level type quinoa.

\begin{tabular}{|c|c|c|c|c|c|c|c|}
\hline Year & Variety & Plot & Sowing date & $\begin{array}{l}\text { Flowering } \\
\text { stage }\end{array}$ & Maturity stage & $\begin{array}{l}\text { Day length from } \\
\text { flowering to } \\
\text { maturity (h) }\end{array}$ & $\begin{array}{l}\text { Maximum } \\
\text { temperature of each } \\
\text { day from flowering to } \\
\text { maturity }\left({ }^{\circ} \mathrm{C}\right)\end{array}$ \\
\hline \multirow{9}{*}{2011} & \multirow{3}{*}{ NL-6 } & March & March 29 & May 24 & July 1 & $14.1-14.3$ & $17.6-31.3$ \\
\hline & & June & June 17 & July 22 & August 22 & $13.0-14.3$ & $24.3-33.0$ \\
\hline & & September & September 22 & November 7 & December 19 & $9.5-10.5$ & $7.0-25.0$ \\
\hline & \multirow{3}{*}{$\begin{array}{l}\text { Baer } \\
\text { Cajon }\end{array}$} & March & March 29 & May 25 & June 29 & $14.1-14.3$ & $17.6-31.3$ \\
\hline & & June & June 17 & July 17 & August 22 & $13.0-14.3$ & $24.3-33.0$ \\
\hline & & September & September 22 & November 7 & December 12 & $9.5-10.5$ & $7.0-25.0$ \\
\hline & \multirow{3}{*}{ Cauquenes } & March & March 29 & May 28 & July 2 & $14.1-14.3$ & $17.6-31.8$ \\
\hline & & June & June 17 & July 24 & August 29 & $13.0-14.3$ & $24.3-33.0$ \\
\hline & & September & September 22 & November 7 & December 19 & $9.5-10.5$ & $7.0-25.0$ \\
\hline \multirow{3}{*}{2014} & \multirow{3}{*}{ Cauquenes } & March & March 27 & May 17 & July 5 & $13.5-14.3$ & $19.3-29.8$ \\
\hline & & June & June 30 & August 15 & September 13 & $12.4-13.4$ & $23.5-31.9$ \\
\hline & & September & September 13 & November 11 & December 23 & $9.5-10.3$ & $8.6-20.0$ \\
\hline
\end{tabular}


temperatures of each day from flowering to maturity ranged between $17.6^{\circ} \mathrm{C}$ and $31.8^{\circ} \mathrm{C}, 23.5^{\circ} \mathrm{C}$ and $33.0^{\circ} \mathrm{C}$, and $7.0^{\circ} \mathrm{C}$ and $25.0^{\circ} \mathrm{C}$, respectively.

Table 3 shows the date, day length, and maximum temperature of each day from flowering to maturity of the valley-type quinoa. In the sowing plots of March, the flowering period ranged from late May to mid-June, 2012 and 2014; however, did not reach to flowering in 2013. In addition, plants matured in July, 2012. In the sowing plots of June or July, the flowering period occurred in mid-September, and plants matured in October, 2012 with the subsequent flowering period during 2013 not being reached. In the sowing plots of August or September, the flowering period occurred in October, and plants matured from December to January. The day length from flowering to maturity ranged from 14.1 to $14.4 \mathrm{~h}, 10.5$ to $13.0 \mathrm{~h}$, and 9.5 to $11.4 \mathrm{~h}$ in sowing plots of March, June, August, and September, the maximum temperature of each day from flowering to maturity ranged between $19.0^{\circ} \mathrm{C}$ and $30.8^{\circ} \mathrm{C}, 19.4^{\circ} \mathrm{C}$ and $31.7^{\circ} \mathrm{C}, 7.6^{\circ} \mathrm{C}$ and $25.7^{\circ} \mathrm{C}$, respectively.

\subsection{Seed Weight, 1000 Seeds Weight and Seed Number of the Altiplano Type Quinoa}

Table 4 shows the seed weight per pot, 1000 seeds weight and seed number per pot of the Altiplano type quinoa.

Table 3. Growth stage and day length from flowering to maturity stage of valley type quinoa.

\begin{tabular}{|c|c|c|c|c|c|c|c|}
\hline Year & Variety & Plot & Sowing date & $\begin{array}{l}\text { Flowering } \\
\text { stage }\end{array}$ & Maturity stage & $\begin{array}{l}\text { Day length } \\
\text { from } \\
\text { flowering to } \\
\text { maturity } \\
\text { (h) }\end{array}$ & $\begin{array}{l}\text { Maximum } \\
\text { temperature of } \\
\text { each day from } \\
\text { flowering to } \\
\text { maturity }\left({ }^{\circ} \mathrm{C}\right)\end{array}$ \\
\hline \multirow{12}{*}{2012} & \multirow{3}{*}{$\begin{array}{l}\text { Amarilla de } \\
\text { Marangani }\end{array}$} & March & March 27 & June 12 & July 14 & 14.2 - 14.3 & $19.0-29.2$ \\
\hline & & July & July 17 & September7 & October 22 & $11.1-13.0$ & $20.0-31.7$ \\
\hline & & August & August 28 & October 15 & December 1 & $9.6-11.4$ & $9.6-25.7$ \\
\hline & \multirow{3}{*}{ Blanca de Junin } & March & March 27 & June 26 & July 18 & $14.2-14.3$ & $22.0-30.8$ \\
\hline & & July & July 17 & September 18 & October 27 & $10.5-12.4$ & $19.4-29.4$ \\
\hline & & August & August 28 & October 27 & December 14 & $9.5-11.2$ & $8.4-23.5$ \\
\hline & \multirow{3}{*}{ CICA-127 } & March & March 27 & June 19 & July 18 & $14.2-14.3$ & $20.6-30.8$ \\
\hline & & July & July 17 & September 15 & October 22 & $11.0-13.0$ & $20.0-31.5$ \\
\hline & & August & August 28 & October 22 & December 8 & $9.5-11.4$ & $8.4-24.8$ \\
\hline & \multirow{3}{*}{ ECU-420 } & March & March 27 & June 23 & July 18 & $14.2-14.3$ & $20.6-30.8$ \\
\hline & & July & July 17 & September 18 & October 27 & $10.5-12.5$ & $19.4-29.4$ \\
\hline & & August & August 28 & October 24 & December14 & $9.5-11.4$ & $8.4-25.7$ \\
\hline \multirow{9}{*}{2013} & \multirow{3}{*}{ Blanca de Junin } & March & March 26 & - & - & - & - \\
\hline & & June & June 15 & - & - & - & - \\
\hline & & September & September 5 & October 28 & January 6 & $9.5-11.1$ & $7.6-22.0$ \\
\hline & \multirow{3}{*}{ ECU-525 } & March & March 26 & May 29 & July 6 & $14.1-14.4$ & - \\
\hline & & June & June 15 & - & - & - & - \\
\hline & & September & September 5 & October 24 & January 6 & $9.5-11.1$ & $7.6-22.3$ \\
\hline & \multirow{3}{*}{ Ingapirca } & April & April 15 & - & - & - & - \\
\hline & & June & June 15 & - & - & - & - \\
\hline & & September & September 5 & October 28 & January 6 & $9.5-11.1$ & $7.6-22.0$ \\
\hline \multirow{3}{*}{2014} & \multirow{3}{*}{ Narino } & March & March 27 & June 24 & - & - & - \\
\hline & & June & June 17 & September 13 & - & - & - \\
\hline & & August & August 28 & October 24 & December 10 & $9.5-11.1$ & $10.4-22.6$ \\
\hline
\end{tabular}

-: Not extend to flowering or maturity stage.

Table 4. Seed weight, 1000 seeds weight and number of seeds of Altiplano type quinoa.

\begin{tabular}{|c|c|c|c|c|c|}
\hline Year & Variety & Plot & $\begin{array}{l}\text { Seed weight } \\
\quad\left(\mathrm{g} \mathrm{pot}^{-1}\right)\end{array}$ & 1000 seeds weight $(\mathrm{g})$ & $\begin{array}{l}\text { No. of seed. } \\
\left(\operatorname{pot}^{-1}\right)\end{array}$ \\
\hline \multirow{6}{*}{2013} & \multirow{3}{*}{$94 \mathrm{R}$} & March & 23.08 a & $3.2 \mathrm{a}$ & 7,440 a \\
\hline & & June & $13.39 \mathrm{~b}$ & $1.8 \mathrm{c}$ & $7,400 \mathrm{a}$ \\
\hline & & September & $16.75 \mathrm{ab}$ & $2.9 \mathrm{~b}$ & 5,763 a \\
\hline & \multirow{3}{*}{ Isluga } & March & $23.13 \mathrm{a}$ & $2.9 \mathrm{a}$ & $7,950 \mathrm{~b}$ \\
\hline & & June & $20.11 \mathrm{a}$ & $1.8 \mathrm{~b}$ & 11,304 a \\
\hline & & September & $11.69 \mathrm{~b}$ & $2.9 \mathrm{a}$ & $3,743 \mathrm{c}$ \\
\hline \multirow{4}{*}{2014} & \multirow{2}{*}{$94 \mathrm{R}$} & March & 26.0 a & $2.5 \mathrm{a}$ & 9,999 a \\
\hline & & June & $10.8 \mathrm{~b}$ & $2.2 \mathrm{a}$ & $4,815 b$ \\
\hline & \multirow{2}{*}{ Isluga } & March & $30.5 \mathrm{a}$ & $2.6 \mathrm{a}$ & 11,630 a \\
\hline & & June & $7.3 \mathrm{~b}$ & $2.2 \mathrm{~b}$ & $3,468 \mathrm{~b}$ \\
\hline
\end{tabular}


The seed weights of all varieties were the highest in the sowing plots of March. In 2013 and 2014, the seed weights of 94R were significantly higher in the sowing plots of March than that of June. In 2013, the seed weight of Isluga was significantly higher in the sowing plot of March than in that of September, and in 2014, the seed weight of Isluga was significantly higher in the sowing plot of March than in that of June. The 1000 seeds weight of all varieties was the heaviest in the sowing plot of March, and that of 94R and Isluga in 2013 and Isluga in 2014 were significantly higher than in the other sowing plots. In 2013, there was no significant difference in the seed number per pot of 94R among all sowing plots. However, that of Isluga in the sowing plot of June was significantly higher $(\mathrm{P}<0.05)$. In 2014, the seed number of both varieties was significantly higher $(\mathrm{P}<$ 0.05 ) in the sowing plot of March than in that of June.

\subsection{Seed Weight, 1000 Seeds Weight and Seed Number of the Sea-Level Type Quinoa}

Table 5 shows the seed weight per pot, 1000 seeds weight and seed number per pot of the sea-level type quinoa. In 2011 and 2014, the seed weights of all varieties were significantly higher in the sowing plot of March than in the other sowing plots. In 2011, the 1,000 seeds weight of NL-6 was the heaviest in the sowing plot of March, whereas that of Cauquenes was the heaviest in the sowing plot of September. In 2014, the 1,000 seeds weight of Cauquenes was the heaviest in the sowing plot of March. There was no significant difference in the 1000 seeds weight of Baer Cajon among the plots. In 2011 and 2014, the seed number per pot of all varieties was significantly higher in the sowing plot of March than in the other sowing plots.

\subsection{Seed Weight, 1000 Seeds Weight and Seed Number of the Valley Type Quinoa}

Table 6 shows the seed weight per pot, 1000 seeds weight and seed number per pot of the valley type quinoa. Seeds of all varieties in the sowing plot of March were not harvested except for the Amarilla de Marangani variety in 2012. In addition, the seeds of all varieties in the sowing plot of June were not harvested in 2013 and 2014. In contrast, seeds of all varieties in the sowing plots of August or September sowing plots were harvested, and the seed weight in the sowing plots of August or September were significantly higher than that in the sowing plot of June. Except for ECU-420, the 1000 seeds weight of all varieties was significantly higher in the sowing plot of September than in the other sowing plots in 2012. In 2012, 2013, and 2014, the seed number per pot of all varieties was significantly higher in the sowing plot of September than in the other sowing plots.

\section{Discussion}

In general, the day length did not affect the seed growth of the sea-level type quinoa [9] [14]. Although the seed growth of the valley type quinoa was severely suppressed under $15 \mathrm{~h}$ day length, it was not suppressed under 11 $\mathrm{h}$ day length [14]. In addition, Isobe et al. [12] reported that the day temperature did not affect the seed growth of the sea-level type quinoa. In the present study, when the sea-level type seeds were sowed from March to September, the seeds could be gained at maturity in all sowing plots (Table 5). The day length in the sowing plots of March, June, and September from flowering to maturity were from 13.5 to $14.3 \mathrm{~h}, 12.4$ to $14.3 \mathrm{~h}$, and 9.5 to $10.5 \mathrm{~h}$, respectively (Table 2). The maximum temperature of each day in the sowing plots of March, June, and

Table 5. Seed weight, 1000 seeds weight and number of seeds of sea-level type quinoa.

\begin{tabular}{|c|c|c|c|c|c|}
\hline Year & Variety & Plot & $\begin{array}{l}\text { Seed weight } \\
\quad\left(\mathrm{g} \mathrm{pot}^{-1}\right)\end{array}$ & 1000 seeds weight (g) & $\begin{array}{c}\text { No. of seed } \\
\left(\text { pot }^{-1}\right)\end{array}$ \\
\hline \multirow{9}{*}{2011} & \multirow{3}{*}{ NL-6 } & March & 35.9 a & $2.4 \mathrm{a}$ & 14,636 a \\
\hline & & June & $16.9 \mathrm{~b}$ & $2.0 \mathrm{~b}$ & 8,294 b \\
\hline & & September & $4.0 \mathrm{c}$ & $1.6 \mathrm{c}$ & $2,334 \mathrm{c}$ \\
\hline & \multirow{3}{*}{ Baer Cajon } & March & $36.7 \mathrm{a}$ & $2.9 \mathrm{a}$ & $12,589 \mathrm{a}$ \\
\hline & & June & $22.1 \mathrm{~b}$ & $2.1 \mathrm{~b}$ & $10,770 \mathrm{a}$ \\
\hline & & September & $8.4 \mathrm{c}$ & $3.1 \mathrm{a}$ & $2,763 \mathrm{~b}$ \\
\hline & \multirow{3}{*}{ Cauquenes } & March & $27.6 \mathrm{a}$ & $2.3 \mathrm{~b}$ & $12,119 \mathrm{a}$ \\
\hline & & June & $20.1 \mathrm{~b}$ & $2.2 \mathrm{~b}$ & 9,248 a \\
\hline & & September & $9.3 \mathrm{c}$ & $2.7 \mathrm{a}$ & $3,385 b$ \\
\hline \multirow{3}{*}{2014} & \multirow{3}{*}{ Cauquenes } & March & $29.6 \mathrm{a}$ & $2.7 \mathrm{a}$ & $10,636 \mathrm{a}$ \\
\hline & & June & $12.6 \mathrm{~b}$ & $1.8 \mathrm{c}$ & $6,101 \mathrm{~b}$ \\
\hline & & September & $17.4 \mathrm{~b}$ & $2.5 \mathrm{~b}$ & $6,473 \mathrm{~b}$ \\
\hline
\end{tabular}


Table 6. Seed weight, 1000 seeds weight and number of seeds of valley type quinoa.

\begin{tabular}{|c|c|c|c|c|c|}
\hline Year & Variety & Plot & $\begin{array}{l}\text { Seed weight } \\
\quad\left(\mathrm{g} \mathrm{pot}^{-1}\right)\end{array}$ & 1000 seeds weight (g) & $\begin{array}{c}\text { No. of seed } \\
\left(\operatorname{pot}^{-1}\right)\end{array}$ \\
\hline \multirow{12}{*}{2012} & \multirow{3}{*}{ Amarilla de Marangani } & March & $0.4 \mathrm{~b}$ & $1.4 \mathrm{C}$ & $217 \mathrm{c}$ \\
\hline & & July & $4.8 \mathrm{~b}$ & $2.3 \mathrm{~b}$ & $2,124 b$ \\
\hline & & August & $24.2 \mathrm{a}$ & $2.7 \mathrm{a}$ & 9,077 a \\
\hline & \multirow{3}{*}{ Blanca de Junin } & March & - & - & - \\
\hline & & July & $0.1 \mathrm{~b}$ & $0.8 \mathrm{~b}$ & $144 \mathrm{~b}$ \\
\hline & & August & $12.7 \mathrm{a}$ & $1.8 \mathrm{a}$ & $6,987 \mathrm{a}$ \\
\hline & \multirow{3}{*}{ CICA-127 } & March & - & - & - \\
\hline & & July & $1.5 \mathrm{~b}$ & $1.7 \mathrm{~b}$ & 832 b \\
\hline & & August & 20.9 a & $2.8 \mathrm{a}$ & $7,467 \mathrm{a}$ \\
\hline & \multirow{3}{*}{ ECU-420 } & March & - & - & - \\
\hline & & July & $0.1 \mathrm{~b}$ & $1.1 \mathrm{a}$ & $70 \mathrm{~b}$ \\
\hline & & August & $13.7 \mathrm{a}$ & $1.7 \mathrm{a}$ & 7,633 a \\
\hline \multirow{9}{*}{2013} & \multirow{3}{*}{ Blanca de Junin } & March & - & - & - \\
\hline & & June & - & - & - \\
\hline & & September & 7.49 & 1.8 & 3,827 \\
\hline & \multirow{3}{*}{ ECU-525 } & March & - & - & - \\
\hline & & June & - & - & - \\
\hline & & September & 21.0 & 2.7 & 7,800 \\
\hline & \multirow{3}{*}{ Ingapirca } & April & - & - & - \\
\hline & & June & - & - & - \\
\hline & & September & 13.3 & 2.7 & 5,051 \\
\hline \multirow{3}{*}{2014} & \multirow{3}{*}{ Narino } & March & - & - & - \\
\hline & & June & - & - & - \\
\hline & & September & 11.7 & 2.0 & 5,774 \\
\hline
\end{tabular}

-: Not extend to maturity stage.

September from flowering to maturity ranged from $17.6^{\circ} \mathrm{C}$ to $31.8^{\circ} \mathrm{C}, 23.5^{\circ} \mathrm{C}$ to $33.0^{\circ} \mathrm{C}$ and $7.0^{\circ} \mathrm{C}$ to $25.0^{\circ} \mathrm{C}$, respectively. Thus, we concluded that the seed growth of the sea-level type quinoa was not considerably suppressed by the day length and maximum temperature. However, the seed weight and seed number of all sea-level type varieties in the sowing plots of March were higher than those in the other sowing plots (Table 5). These results are consistent with those reported by Ujiie et al. [14] and Isobe et al. [12]. Thus, to gain a high seed yield of the sea-level-type quinoa, March is the optimum sowing time in south Kanto, Japan.

When the valley-type seeds were sowed from March to June, the seeds did not gain in this experiment, except in 2012 (Table 6). In 2012, the seed weights and seed numbers in sowing plots of March and June were lower than those in the sowing plot of September. Ujiie et al. [14] reported that the valley-type seeds were severely suppressed under the long-day condition after flowering. In the present study, the day lengths in the sowing plots of March and June from flowering to maturity were almost as the long-day condition of $>12 \mathrm{~h}$ (Table 3). Thus, to gain seeds of the valley type quinoa, seeds should be sowed under $11 \mathrm{~h}$ day length conditions from flowering to maturity. Isobe et al. [12] reported that the decrease in day temperature from $30^{\circ} \mathrm{C}$ to $20^{\circ} \mathrm{C}$ increased 1000 seeds weight and seed weight in valley type. In 2012, the maximum temperature of each day from flowering to maturity in the sowing plots of March and June were higher than that in the sowing plot of September (Table 3). Thus, the reason for a lower seed weight in the sowing plots of March and June is the long day and higher day temperature conditions after flowering. To obtain a high seed yield of the valley type quinoa, the optimum sowing time in south Kanto, Japan is from August to September.

Ujiie et al. [14] and Isobe et al. [12] used one variety of the sea-level and valley type quinoa, and not the Altiplano type quinoa in their experiments. Thus, the optimum sowing time is not clear for the Altiplano type quinoa in Japan. Risi and Galwey [7] [8] reported that the Altiplano type quinoa was more cognate with the valley type than with the sea-level type quinoa. Thus, we considered that the Altiplano and valley type quinoa have same seed growth reaction for day length and day temperature. However, when the Altiplano type quinoa was sowed from March to September, seeds were gained in all sowing plots. In addition, the seed yields of the Altiplano and the sea-level type quinoa were higher in the sowing plots of March than in the other sowing plots (Table 4). Thus, we concluded that the Altiplano and sea-level type quinoa have almost the same seed growth reaction for day length and day temperature. In addition, to obtain a high seed yield of the Altiplano type quinoa, the optimum sowing time is almost the same as that of the sea-level type. In conclusion, the optimum sowing times in Kanto for obtaining a high seed yield is March for the Altiplano and sea-level type quinoa and from 
August to September for the valley type quinoa.

\section{Conclusion}

The objective of the present study was to determine the optimum sowing time of three quinoa ecotypes (Altipllano, sea level, and valley) for high seed yields in south Kanto, Japan. In this pot experiments, the quinoa seeds were sown from March to September, 2012, 2013 and 2014. To gain a high seed yield of the sea-level and Altiplano type quinoa, March was the optimum sowing time. On the other hand, for valley type quinoa, the optimum sowing time was from August to September.

\section{References}

[1] Repo-Carrasco, R., Espinoza, C. and Jacobsen, S.-E. (2003) Nutritional Value and Use of the Andean Crops Quinoa (Chenopodium quinoa) and Kañiwa (Chenopodium pallidicaule). Food Reviews International, 19, 179-189. http://dx.doi.org/10.1081/FRI-120018884

[2] Costa Tártara, S.M., Manifesto, M.M., Bramardi, S.J. and Bertero, H.D. (2012) Genetic Structure in Cultivated Quinoa (Chenopodium quinoa Willd), a Reflection of Landscape Structure in Northwest Argentina. Conservation Genetics, 13, 1027-1038.

[3] Fuentes, F.F., Martinez, E.A., Hinrichsen, P.V., Jellen, E.N. and Maughan, P.J. (2009) Assessment of Genetic Diversity Patterns in Chilean Quinoa (Chenopodium quinoa Willd) Germplasm Using Multiplex Fluorescent Microsatellite Markers. Conservation Genetics, 10, 369-377.

[4] Galwey, N.W. (1989) Quinoa. Biologist, 36, 267-274.

[5] Wilson, H.D. (1990) Quinua and Relatives (Chenopodium sect. Chenopodium subsect. Cellulata). Economic Botany, 44, 92-110.

[6] Risi, J. and Galwey, N.W. (1984) The Chenopodium Grains of the Andes : Inca Crops for Modern Agriculture. Advanced in Applied Biology, 10, 145-216.

[7] Risi, J. and Galwey, N.W. (1989) The Pattern of Genetic Diversity in the Andean Grain Crop Quinoa (Chenopodium quinoa Willd) II. Multivariate Methods. Euphytica, 41, 135-145.

[8] Risi, J. and Galwey, N.W. (1989) The Pattern of Genetic Diversity in the Andean Grain Crop Quinoa (Chenopodium quinoa Willd.) I. Associations between Characteristics. Euphytica, 41, 147-162.

[9] Bertero, H.D., King, R.W. and Hall, A.J. (1999) Photoperiod-Sensitive Development Phases in Quinoa (Chenopodium quinoa Willd.). Field Crops Research, 60, 231-243. http://dx.doi.org/10.1016/S0378-4290(98)00128-2

[10] Cheristiansen, J.L., Jacobsen, S.-E. and Jørgensen, S.T. (2010) Photoperiodic Effect on Flowering and Seed Development in Quinoa (Chenopodium quinoa Willd.). Acta Agriculturae Scandinavia Section B-Soil and Plant Science, 60, 539-544. http://dx.doi.org/10.1080/09064710903295184

[11] Hirich, A., Choukr-Allah, R. and Jacobsen, S.-E. (2014) Quinoa in Morocco-Effect of Sowing Dates on Development and Yield. Journal of Agronomy and Crop Science, 200, 371-377. http://dx.doi.org/10.1111/jac.12071

[12] Isobe, K., Ujiie, K., Hitomi, S., Furuya, Y. and Ishii, R. (2012) Agronomic Studies on Quinoa (Chenopodium quinoaWilld.) Cultivation in Japan-Effects of Day and Night Temperature after Flowering Time on Seed Thickening. Japanese Journal of Crop Science, 81, 167-172.

[13] Risi, J. and Galwey, N.W. (1991) Effects of Sowing Date and Sowing Rate on Plant Development and Grain Yield of Quinoa (Chenopodium quinoa) in a Temperate Environment. Journal of Agricultural Science, 117, 325-332. http://dx.doi.org/10.1017/S002185960006706X

[14] Ujiie, K., Sasagawa, R., Yamashita, A., Isobe, K. and Ishii, R. (2007) Agronomic Studies on Quinoa (Chenopodium quinoa Willd.) Cultivation in Japan-I. Determination of the Proper Seeding Time in the Southern Kanto District for Good Performance of the Grain Yield. Japanese Journal of Crop Science, 76, 59-64.

[15] Aguilar, P.C. and Jacobsen, S.-E. (2003) Cultivation of Quinoa on the Peruvian Altiplano. Food Reviews International, 19, 31-41. http://dx.doi.org/10.1081/FRI-120018866

[16] Bertero, H.D. (2003) Response of Developmental Processes to Temperature and Photoperiod in Quinoa (Chenopodium quinoa Willd.). Food Reviews International, 19, 87-97. http://dx.doi.org/10.1081/FRI-120018870

[17] Armeja, I., Tanwar, B. and Chauhan, A. (2015) Nutritional Composition and Health Benefits of Golden Grain of 21 Century, Quinoa (Chenopodium quinoaWilld.): A Review. Pakistan Journal of Nutrition, 14, 1034-1040. http://dx.doi.org/10.3923/pjn.2015.1034.1040

[18] Dini, I., Tenore, G.C. and Dini, A. (2005) Nutritional and Antinutritional Composition of Kancolla Seeds: An Interest- 
ing and Underexploited Andine Food Plant. Food Chemistry, 92, 125-132. http://dx.doi.org/10.1016/j.foodchem.2004.07.008

[19] Konishi, Y. (2002) Nutritional Characteristics of Pseudocereal Amaranth and Quinoa: Alternative Foodstuff for Patients with Food Allergy. Journal of Japan Society of Nutrition and Food Sciences, 55, 299-302.

[20] Konishi, Y. (2003) Nutritional Characteristics of Quinoa Seeds and Their Application to Food Uses. Millet Newsletter, 18, 11-15. 